\title{
Dissimilar effects of human and elephant disturbance on woodland structure and functional bird diversity in the mopane woodlands of Zambia
}

\author{
Hemant G. Tripathi $[$ - Tiwonge I. Mzumara • Rowan O. Martin • \\ Catherine L. Parr · Chaona Phiri · Casey M. Ryan
}

Received: 4 June 2018/ Accepted: 25 January 2019/Published online: 19 February 2019

(C) The Author(s) 2019

\begin{abstract}
Context Humans and elephants are major disturbance agents in the African savanna woodlands. While both species remove trees, humans selectively harvest larger stems, which are less vulnerable to elephants. Increasing human pressures raise the question of how the altered disturbance regime will modify woodland structure, and in turn biodiversity and ecosystem function.
\end{abstract}

Electronic supplementary material The online version of this article (https://doi.org/10.1007/s10980-019-00774-2) contains supplementary material, which is available to authorized users.

H. G. Tripathi $(\bowtie)$. C. M. Ryan

School of GeoSciences, University of Edinburgh,

Edinburgh EH9 3FF, UK

e-mail: hgtripathi05@gmail.com

T. I. Mzumara · R. O. Martin

FitzPatrick Institute of African Ornithology, University of

Cape Town, Cape Town 7700, South Africa

\section{T. I. Mzumara}

Malawi University of Science and Technology, Along

Goliati Road - Near Ndata Farm, Limbe 5196, Malawi

R. O. Martin

Africa Conservation Programme, World Parrot Trust,

Glanmor House, Hayle TR27 4HB, UK
Objectives Here we investigate this process in the mopane woodlands of Zambia by examining relationships between woodland structure, species and functional bird diversity, and human and elephant disturbance intensity.

Methods We conducted a single-season comparison of 178 plots from 45 sites using Bayesian mixed models.

Results The effect of elephants on tree density $(-7.7 \pm 1.6 \%$; deviation from intercept $)$ and bird species richness $(-15 \pm 6 \%)$ was greater than that of humans (density: $-3.5 \pm 1.5 \%$; bird richness: $-11.6 \pm 4.7 \%$ ). Despite this, elephants did not significantly affect woody biomass or functional bird

\section{L. Parr}

School of Environmental Sciences, University of

Liverpool, Liverpool L69 3GP, UK

\section{L. Parr}

Department of Zoology \& Entomology, University of Pretoria, Pretoria 0002, South Africa

\section{L. Parr}

School of Animal, Plant and Environmental Sciences, University of the Witwatersrand, Wits 2050, South Africa

C. Phiri

BirdWatch Zambia, Lusaka 10101, Zambia 
diversity, whereas humans had a negative effect on both (woody biomass: $-9.3 \pm 2.3 \%$; functional bird diversity: $-5 \pm 2 \%$ ). Elephants were associated with reductions in species and functional turnover $(5.3 \pm 2.5 \%$ and $6 \pm 3 \%$, respectively).

Conclusions Replacement of elephants by humans is likely to reduce woody biomass and functional bird diversity affecting the woodland structure, sustainability, and functioning. Concentrated elephant disturbance could lead to spatial homogeneity in bird species and functional compositions, potentially reducing the spatial resilience of bird communities. This is the first study to highlight how the difference between elephant and human disturbances leads to dissimilar effects on biodiversity.

Keywords Savanna woodlands - Functional traits · Alpha diversity $\cdot$ Beta diversity $\cdot$ Bayesian mixed models

\section{Introduction}

Humans and elephants are integral and ancient parts of the African savanna woodlands, structuring the ecosystem through disturbance (Ellis 2011; CharlesDominique et al. 2016). However, in recent times their relative influence as disturbance agents has radically changed (Boer et al. 2013); humans have replaced elephants as the dominant disturbance agents with unknown consequences for biodiversity and ecosystem function. As elephants and humans both remove trees (Mograbi et al. 2017), they may appear functionally interchangeable (Hempson et al. 2017), but there are important differences in the way they use savannas and the size of the trees they preferentially remove (Staver and Bond 2014; Woollen et al. 2016; Mograbi et al. 2017). As such, elephants and humans may be modifying woodland structure and thus its biodiversity in dissimilar ways, but the identification of such discrepancies - and the assessment of their effects-has received surprisingly little attention. Here we present a spatial comparison of the effects of disturbance by humans and elephants on (i) structural attributes of the woody vegetation (ii) species and functional diversity of birds in the mopane woodlands of Zambia.
Being dominant land herbivores and bulk feeders, elephants alter the woodland structure by removing trees for forage through pollarding, uprooting, and debarking (O'Connor et al. 2007). They target trees predominantly in the 5-9 $\mathrm{m}$ height range-the elephant browse-trap (Asner and Levick 2012; Staver and Bond 2014) —and, through pushing over and pollarding, they keep patches of trees in suppressed, stunted forms (Styles and Skinner 2000). Elephants repeatedly visit the stunted trees for the nutritious leaves that resprout in response to the extensive browsing (Kohi et al. 2011). However, certain treesdepending on their growth rates and the densities of elephants-episodically escape the elephants' 'browse trap' and grow large enough to become less vulnerable to elephant disturbance (Shannon et al. 2011; Staver and Bond 2014). These large trees possibly counter-balance the woody biomass lost due to elephant-mediated tree removal and suppression at the landscape-scale (Ben-Shahar 1996). These processes maintain the open-canopied structure of savanna woodlands and prevent woody encroachment (Stevens et al. 2016). Furthermore, the elephantmaintained open woodlands containing large trees are associated with woodland-specific co-occurring species like the cavity-nesting and ground-foraging Lilian's Lovebird Agapornis lilianae (Mzumara et al. 2014), hence, elephants also facilitate the distinct species and functional diversity of the savanna woodlands (Botes et al. 2006; Pringle 2008).

In contrast to elephants, humans selectively harvest_consume (Archibald 2016)_large trees for fuelwood, construction and timber, especially those that produce good quality, slow-burning commercial charcoal (Woollen et al. 2016). The selective removal of large trees means that woody biomass in the humanutilized woodlands declines at a much faster rate than tree density (Woollen et al. 2016). As a result, the woodlands may transform into novel ecosystems composed of stems of smaller sizes, with increased shrub vegetation in the areas where large trees formerly persisted (Hosier 1993; Kalema and Witkowski 2012). Furthermore, once the large trees are depleted, the smaller, less desirable trees are also harvested to meet the increasing demands for fuelwood, further reducing the remaining woody biomass (Hosier 1993). There is therefore potentially no escape for trees from the human trap. The human-utilized woodlands devoid of large trees and increased ground 
vegetation are known to cause a switch to nonwoodland and shrubby habitat-preferring faunal communities (Botes et al. 2006; Seymour and Dean 2010).

Increased hunting and anthropogenic land-use change have reduced elephant population sizes and compressed their distributions into a small network of protected areas - a fraction of their historical ranges (Robson et al. 2017). Humans have therefore replaced elephants as one of the dominant disturbance agents in African savanna woodlands (Hempson et al. 2017). To understand the consequences of this replacement, a comparison of the effects of human and elephant disturbance on woodland structure and biodiversity is required. However, to our knowledge, there are only two human-elephant effect comparisons. Botes et al. (2006) showed that dung beetle assemblages in elephant disturbed forests were more similar to undisturbed forests $(73 \%$ similar) than the assemblages in human-disturbed forests were (50\% similar). Mograbi et al. (2017) compared biennial tree fall rates and demonstrated that elephant and human disturbances affect all woody height classes with both inducing shrubland conversion. While Botes et al. (2006) did not investigate functional diversity patterns, Mograbi et al. (2017) is restricted to a single attribute of the woodland structure - the tree density. Comparisons incorporating multiple attributes of the woodland structure-woody biomass, tree size, and ground cover, and biodiversity-species and functional $\alpha$-and $\beta$-diversity are required in order to fully assess potential differences between human- and elephant-mediated change. Separate studies of human and elephant disturbance suggest that while anthropogenic impacts on woody biomass and biodiversity are often negative (but see Luck 2007; Winfree et al. 2007; Andela et al. 2017 for exceptions), elephant impacts are variable, and dependent upon elephant density as well as factors such as fencing, proximity to artificial water bodies, rainfall and soil character (Guldemond and Van Aarde 2008; Guldemond et al. 2017). Furthermore, studies have demonstrated that increased elephant concentrations may reduce landscape heterogeneity through size-structured tree removal (Asner and Levick 2012), with possible effects on the landscape-wide species and functional $\beta$-diversity of faunal communities (Herremans 1995; Cumming et al. 1997). Thus, human and elephant disturbance may be associated with divergent consequences, an understanding of which is paramount for the effective management of the savanna woodlands.

We hypothesized that elephant and human disturbance would reduce tree density but have different effects on other attributes-woody biomass, tree size, and ground cover - of the woodland habitat, and consequently bring about dissimilar impacts on species and functional diversity of birds. We tested this hypothesis in the mesic mopane woodlands of Zambia where elephant-dominated areas (unfenced national parks and game reserves), human-utilized lands (non-protected areas near urban centres), and low-disturbance regions (remote non-protected areas) are spatially exclusive. We chose birds as the taxonomic group for this study because they are relatively visible and easy to identify (Bibby 1999), are sensitive to habitat structural modifications (Owens and Bennett 2000) and are good indicators of effects of habitat filtering process (Benítez-López et al. 2017).

\section{Methods}

Study area

The study area spans the distributional range of mopane woodlands in Zambia -identified using White's African vegetation map (White 1983) which includes the eastern part of the country from north to south, covering the Luangwa, Luano and Zambezi valleys (Fig. 1). The area includes three national parks (North Luangwa, South Luangwa, and Lower Zambezi), two major charcoal and timber production regions (Chirundu and Chipata; (Gumbo et al. 2013), and remote areas of low human-utilization (Luano). The Zambian mopane region is mainly occupied by alkaline alluvial soils, and receives mean annual rainfall of 750-1000 mm in central-north and $500-750 \mathrm{~mm}$ in the south (Nkhuwa et al. 2016). Monospecific stands of Colophospermum mopane dominate the region, along with occasionally cooccurring species such as Combretum apiculatum, $C$. zeyheri, Terminalia prunioides and T. sericea (Martini et al. 2016).

At the beginning of the 2015 dry season (May-July) we measured woodland vegetation structure and disturbance in 178 plots clustered within 45 sites 


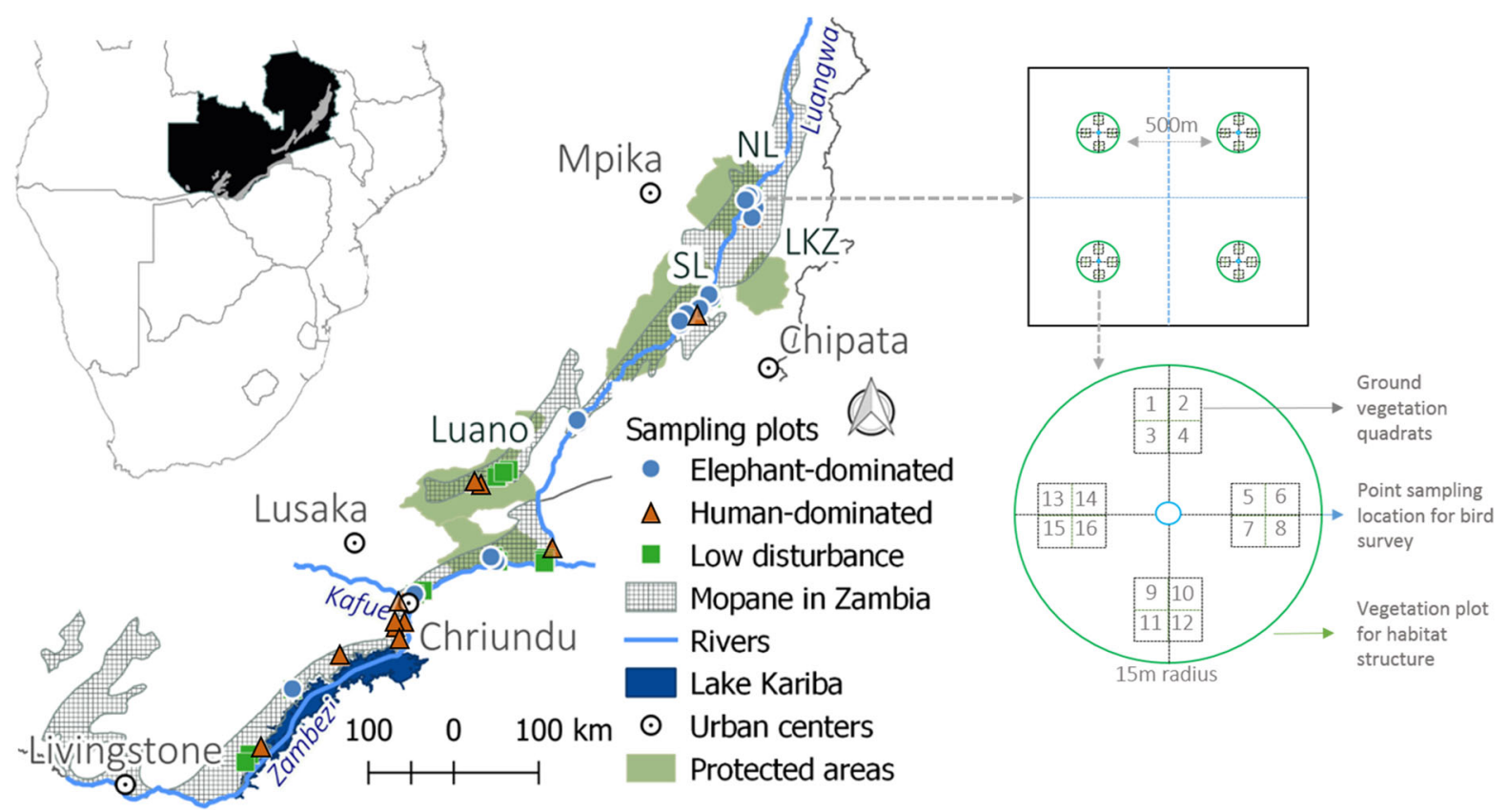

Fig. 1 Distribution of sampling sites in the mopane woodlands of Zambia (left) with national parks ( $L Z$ Lower Zambezi, $S L$ South Luangwa, $N L$ North Luangwa, $L Z K$ Lukusuzi) and game reserve (Luano), the basin of two major rivers (Luangwa and Zambezi), Lake Kariba and main urban centres (Chirundu and Chipata) around the sampling region. The 45 sites $\left(1 \mathrm{~km}^{2}\right.$ grid;

(grids of $1 \mathrm{~km}^{2}$ ). At the centre of 120 plots from 30 sites, we collected bird diversity data using pointcounts. Each site (except one for the woodland structure, where we could measure only 2 plots) contained 4 circular plots $500 \mathrm{~m}$ apart. The sites were distributed across the mopane landscape from south (Sinazeze; - 17.46732, 27.29626) to north (North Luangwa; - 11.91523, 32.40934), were at least $250 \mathrm{~m}$ away from any tar road, large river or waterbody, were at least $1 \mathrm{~km}$ away from each other, and had a mean altitude below $750 \mathrm{~m}$.

\section{Woodland structure}

In each circular plot, for all tree stems $\geq 10 \mathrm{~cm} \mathrm{DBH}$ (diameter at breast height, $1.3 \mathrm{~m}$ ) we identified species, measured DBH and counted the total number of stems where $2 \mathrm{~cm}<\mathrm{DBH}<10 \mathrm{~cm}$. To estimate ground vegetation cover (hereafter ground cover), we used four smaller quadrats of $1 \mathrm{~m}^{2}$ placed within the circular plot, one in each cardinal direction, and at $10 \mathrm{~m}$ from the centre. Each ground cover quadrat was top right) contained 178 circular sampling plots $500 \mathrm{~m}$ apart. Point counts for birds were undertaken in the centre of plots (bottom right). Within each plot, four $1 \mathrm{~m}^{2}$ quadrats divided into 16 blocks (bottom right) were used for ground vegetation surveys. The inset shows regional context-mopane woodlands (light grey) in Zambia (black) and southern Africa

subdivided into 4 blocks such that in each circular plot, the quadrats together constituted a total of 16 blocks. The number of blocks occupied by ground vegetation was used as an index of ground cover. For unidentified trees, photographs and sample specimens were collected for identifications with help of botanists in Lusaka and online floras (Bingham et al. 2017; Hyde et al. 2017).

\section{We computed five variables to represent woodland structure}

1. Density $\left(N\right.$, total stems ha $\left.{ }^{-1}\right)$, the number of tree stems $\geq 10 \mathrm{~cm} \mathrm{DBH}$.

2. Small stem density $\left(N_{\mathrm{s}}\right.$, stems ha $\left.{ }^{-1}\right)$, the number of tree stems where $2<\mathrm{DBH}<10 \mathrm{~cm}$.

3. Woody biomass $\left(B, \mathrm{tC} \mathrm{ha}^{-1}\right)$, calculated following the allometric Eq. $\left(0.0267 \times \mathrm{DBH}^{2.59}\right)$ in Ryan et al. (2011).

4. Tree size $(D, \mathrm{~cm})$, mean DBH of all tree stems.

5. Ground cover $(C)$, the proportion of the total number of blocks covered by ground vegetation. 
Bird species and functional diversity variables

Bird data were collected at the centre of each circular plot between 6 and 9 am by the point-sampling presence-absence survey method (Gregory et al. 2004), where the bird species seen or heard during the sampling period of $15 \mathrm{~min}$ were listed. For each recorded species, we collected trait information from Elton Traits 1.0 (Wilman et al. 2014). The trait values were the relative percentages of 10 diet and seven foraging strata categories, activity time (categorical, 1 or 0 ) and body mass (g) - table of traits provided in supplementary information (SI; Table S1). For four unidentified species, mean values were used (the analysis was also conducted after removing the unidentified species; this did not make any significant difference, so only results using the mean values are presented).

We computed $\alpha$ - and $\beta$-diversities for species and functional type from the survey data. Since the main objective of this study was to examine changes in composition due to species or functional replacement, we used only the turnover component of the multicomponent (nestedness and turnover) $\beta$-diversity (Baselga 2010). Species $\alpha$-diversity (species richness, $S$ ) is the total number of species recorded in each plot and is conditional upon the assumption that the bias due to imperfect detection would be uniform (since sampling effort was constant). Species $\beta$-diversity was derived by computing the incidence-based mean pairwise Simpson dissimilarity in species-presence between communities $\left(S_{\beta s i m}\right)$, following Baselga (2010).

For functional diversity, we first made a BrayCurtis pairwise functional distance matrix of species. We then computed the mean functional pairwisedistance (FD) between species in a community as a measure of functional $\alpha$-diversity, following Swenson (2014). Further, using a functional dendrogram (Figure S2 in SI), derived from the functional distance matrix, and the presence-absence matrix of bird species in each community, we calculated community-level pairwise Simpson dissimilarity in functional space as a measure of functional $\beta$-diversity $\left(\mathrm{FD}_{\beta \operatorname{sim}}\right)$, following Leprieur et al. (2012) and Melo et al. (2014).
Human and elephant disturbance

We counted the number of stems impacted by elephants, evidenced by knocked down, pollarded, broken, or bark-stripped stems, and affected by humans, evidenced by cut stems. As an indicator of disturbance, we computed the $\%$ of the total number of stems in a plot that were affected by elephants $\left(I_{E l e}\right)$ and humans $\left(I_{\text {Human }}\right)$. We also derived mean pairwise geographical distance $(g)$ between plots to account for spatial autocorrelation.

Statistical analyses

For descriptive analysis of differential impacts and size-class specific variances, we classified the plots into three categories: Low disturbance $\left(n=85,\left(I_{\text {Ele }}\right.\right.$ and $\left.I_{\text {Human }}<20 \%\right)$, Human-dominated $(n=51$, $100 \geq I_{\text {Human }} \geq 20 \%$ and $0 \leq I_{\text {Ele }}<20 \%$ ), and Elephant-dominated $\left(\mathrm{n}=40, \quad 100 \geq I_{\text {Ele }} \geq 20 \%\right.$ and $0 \leq I_{\text {Human }}<20 \%$ ). The number of plots where both disturbances occurred were few $\left(\mathrm{n}=2, I_{\text {Ele }}\right.$ and $I_{\text {Human }}>20 \%$ ) and hence were excluded.

The human population density of the study region has doubled since the 1970s (Ohadike and Tesfaghiorghis 1975; Hoare and Toit 1999) whilst the population of elephants has reduced 10-fold (Kampamba et al. 2003; Chomba et al. 2012). As human population increased, elephant densities reduced and their distribution became restricted to the few protected areas (Boer et al. 2013). In this study, therefore, the elephant-dominated areas-mainly national parks, represent the early stage in this transition to human domination, whilst non-protected areas near towns represent the final stage of transition. Areas with low activity of both elephants and humans-principally game management areas-are considered "transitional" (Table 1).

To examine the effects of disturbance on woodland structure and bird diversity, we constructed mixed models. We used each of the woodland structure (Eq. 1) and bird diversity (Eq. 2) variables, respectively, as responses, disturbance variables and geographical distance as main effects, and sites within the plots as nested random effects.

$$
\begin{aligned}
& W_{i}=\alpha_{j}+\beta_{1} I_{\text {Human }(i)}+\beta_{2} I_{\text {Ele }(i)}+\beta_{3} g_{i} \\
& D_{i}=\alpha_{j}+\beta_{1} I_{\text {Human }(i)}+\beta_{2} I_{\text {Ele }(i)}+\beta_{3} g_{i}
\end{aligned}
$$


Table 1 Human and elephant densities in the study areas. Source: Human densities-Ohadike and Tesfaghiorghis (1975), Hoare and Toit (1999), Elephant densities_Kampamba et al. (2003), Chomba et al. (2012) and Boer et al. (2013)

\begin{tabular}{|c|c|c|c|}
\hline Impact categories & Locations & Human density & Elephant density \\
\hline Human-dominated & $\begin{array}{l}\text { Areas around Lake Kariba (Sinazongwe, } \\
\text { Gwembe, Siavonga, and Chirdundu) }\end{array}$ & $25-46 \mathrm{~km}^{-2}$ & $0-0.1 \mathrm{~km}^{-2}$ \\
\hline Elephant-dominated & $\begin{array}{l}\text { Lower Zambezi, South Luangwa, North } \\
\text { Luangwa national parks }\end{array}$ & $6-8 \mathrm{~km}^{-2}$ & $0.6-2 \mathrm{~km}^{-2}$ \\
\hline Low disturbance & Luano and parts of Luangwa valleys & $3-6 \mathrm{~km}^{-2}$ & $0.1-0.3 \mathrm{~km}^{-2}$ \\
\hline
\end{tabular}

where, $W$ is the woodland structure variable $\left\{\mathrm{N}, \mathrm{N}_{\mathrm{s}}, \mathrm{B}\right.$, $\mathrm{D}$, and $\mathrm{C}\}, \mathrm{D}$ is the diversity variable $\left\{\mathrm{S}, \mathrm{S}_{\beta \text { sim }}, \mathrm{FD}\right.$, $\left.\mathrm{FD}_{\beta \text { sim }}\right\}$ for plot i $\{1 . .0 .178\}, \alpha$ and $\beta$ are parameters to be estimated from the model, $\alpha_{j}$ is random effect of site $\mathrm{j}\{1 . .0 .45\}$ within which the plots are clustered, and $\alpha_{j} \sim \operatorname{Normal}\left(\mu_{\alpha} \sigma_{\alpha}^{2}\right)$.

To explain the community-level patterns of bird diversity better, we also investigated the effects of disturbance on species presence (Eq. 3).

$S p_{i}=\alpha_{j}+\beta_{1} I_{\text {Human }(i)}+\beta_{2} I_{\text {Ele }(i)}+\beta_{3} g_{i}$

where $S p$ is the species presence \{species $1 \ldots 132$ \}.

For all woodland structure and bird diversity variables (except species richness), we fitted a linear mixed model with normal distribution. We assessed the habitat and diversity variables for normality, and subsequently $\log _{10^{-}}$(hereafter $\log$ ) transformed the non-normal variables, $N, N_{\mathrm{s}}, B$, and $D$. For bird species richness and incidence, we fitted Poisson and Bernoulli random-effect models, respectively.

We also ran the above models including environmental variables (Relative elevation, Mean Annual Precipitation-MAP, Mean Annual Precipitation-MAT, and Soil—soil type cluster) as linear predictors.

We analysed models using Bayesian methods (Kéry and Royle 2016) implemented in WinBUGS. We provided non-informative flat priors and used three Markov Chain Monte Carlo (MCMC) chains, with 75,000 total iterations each. The first 25,000 iterations were discarded as burn-into remove transient states and attain equilibrium distribution. From the remaining 50,000 total iterations, we selected samples after every 50 iterations (thinning), thus yielding 3000 samples from all three chains for posterior inference. We checked model convergence using the Gelman-Rubin convergence diagnostic
(Gelman and Rubin 1992), with potential scale reduction factor values approaching 1 considered acceptable (Kéry and Royle 2016). We used the 95\% Bayesian Credible Interval (CI) to indicate significant effects and \% deviation from the intercept as the standard effect size (standardised coefficients \pm standard error).

Analyses were conducted using R statistical software version 3.4.2 ( $\mathrm{R}$ Core Team 2017). We used the vegan package (Oksanen et al. 2016) to compute species richness, adespatial (Dray et al. 2016) for species beta diversities, and CommEcol (Melo 2016) for functional beta diversities. For FD we used the codes by Swenson (2014). We used jagsUI (Kellner 2015) for calling WinBUGS and exporting results in R. Figures were drawn using ggplot2 (Wickham 2009).

\section{Results}

We recorded a total of 2572 tree stems belonging to 75 species with mean DBH of $23.3 \mathrm{~cm}(\mathrm{SE} \pm 0.3 \mathrm{~cm})$, plot level stem density of $204 \pm 12$ stems ha $^{-1}$, woody biomass of $40 \pm 3 \mathrm{tC} \mathrm{ha}^{-1}$ and ground cover of $70 \pm 2 \%$. C. mopane was the most dominant tree species, accounting for $\sim 90 \%$ of the total woody biomass and occurring in $\sim 95 \%$ of the plots. Aristida (Occurrence $=48 \%$ ), Chloris $(33 \%)$, and Eragrostis $(26 \%)$ were the dominant grass genera and Duosperma (43\%), Blepharis (38\%), and Justicia (28\%) were the common herb genera. I Iuman was significantly lower in protected areas (mean $10 \pm$ SE $2 \%$ ) than non-protected areas $(27 \pm 4 \%)$, whereas $I_{\text {Ele }}$ was lower in non-protected areas $(2.5 \pm 1.3 \%)$ than protected areas $(17.5 \pm 2.3 \%)$. 
The stem-size distribution in this study followed the typical reverse-j shaped, characterized by the dominance of stems in smaller size classes followed by decreasing number of stems of larger size classes. Stemsize distribution differed between human- and elephantdominated areas. In comparison to the low disturbance plots, the human-dominated plots contained fewer number of large-size stems (Fig. 2a), whereas, the Elephant-dominated plots comprised a relatively longer tail of stems in large-size classes (Fig. 2b).

As expected, both $I_{\text {Human }}$ and $I_{\text {Ele }}$ were negatively associated with stem density, but they affected woody biomass, mean DBH, and small-stem density differently (Fig. 3, coefficient plots in SI-Figure S3), resulting in different stand structures (Fig. $4 \mathrm{a}-\mathrm{c}$ ). Although the effect of $I_{E l e}(-7.7 \pm 1.6 \%)$ on stem density was twice that of $I_{\text {Human }}(-3.5 \pm 1.4 \%), I_{\text {Ele }}$ did not significantly affect the woody biomass, whereas $I_{\text {Human }}$ had a negative effect $(-9.3 \pm$ $2.7 \%$ ). Further, mean DBH was associated positively with $I_{\text {Ele }}(5.4 \pm 1.2 \%)$ and negatively with $I_{\text {Human }}$ $(-1.8 \pm 1.1 \%$; only significant at $90 \% \mathrm{CI})$. The small-stem density significantly increased with $I_{\text {Human }}$ $(15.7 \pm 7.5 \%)$ but did not change with $I_{\text {Ele }}$. Ground cover increased with mean geographic distance between plots and did not show any significant relationship with $I_{H u m a n}$ or $I_{E l e}$.

$I_{\text {Human }}$ and $I_{\text {Ele }}$ were both associated with declining bird species richness but affected the other bird diversity variables differently (Fig. 5; coefficient plots in SI-Figure S4). $I_{E l e}$ had a stronger effect on species richness $(-15.5 \pm 6.2 \%)$ than $I_{\text {Human }}(-11.7 \pm$ $4.7 \%)$ and was associated with a reduction in $S_{\beta \text { sim }}$ $(-5.4 \pm 2.5 \%)$, while $I_{\text {Human }}$ showed no effect.
Despite the negative effects on $\alpha$ - and $\beta$-diversities, $I_{\text {Ele }}$ did not significantly affect $F D$, although $F D_{\beta \text { sim }}$ did reduce with increasing $I_{\text {Ele }}(-4.9 \pm 2.8 \%)$. In contrast, $I_{\text {Human }}$ was associated with reductions in $F D$ $(-4.3 \pm 1.8 \%)$ but had no effect on $F D_{\beta \text { sim. }}$.

The bird species incidence models suggested that more species showed a significantly negative association with $I_{\text {Human }}(\mathrm{n}=31)$ than $I_{\text {Ele }}(\mathrm{n}=18)$. The species negatively affected by $I_{E l e}$ were primarily insectivorous habitat generalists (Terpsiphone viridis and Tchagra australis), non-mopane species (Prionops retzii, Merops pusillus) and species associated with regrowing woodlands (Camaroptera brachyura and Prinia subflava). Those that increased with $I_{\text {Ele }}$ were mainly woodland-preferring seed eaters and ground foragers (mopane specialists Agapornis lilianae and Emberiza flaviventris), woodland-specific insectivores (Lamprotornis mevesii and Nectarinia amethystina), and plant-eating habitat generalists (Estrilda astrild).

In contrast, the $I_{\text {Human }}$ positively affected bird species were the insectivorous habitat generalists (Cisticola fulvicapilla, Uraeginthus angolensis, Salpornis spilonotus, and Lanius collaris) and farmlandgrassland preferring seed eaters (Euplectes orix and Quelea quelea). The negatively affected species in response to $I_{\text {Human }}$ mainly contained a large pool of woodland-specific birds-fruit, nectar and other plantpart eaters (Estrilda astrild, Anthreptes collaris, Lybius torquatus, Nectarinia senegalensis, Serinus mozambicus, Trachyphonus vaillantii, Urocolius indicus), ground foragers (Bucorvus cafer, Francolinus adspersus, and Francolinus coqui) and insectivores (mopane specialists Parus niger and Thripias (a) Stem-size distribution

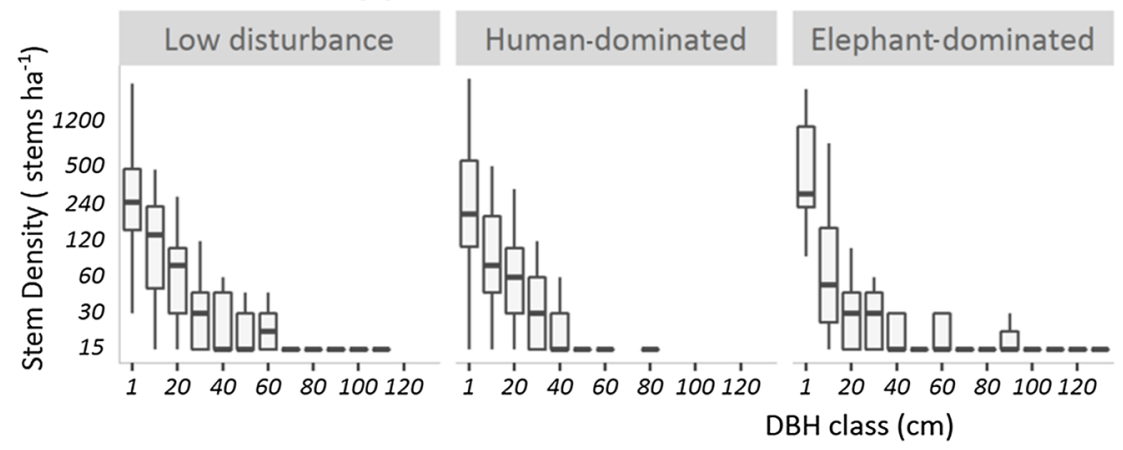

(b) Stem-size slope

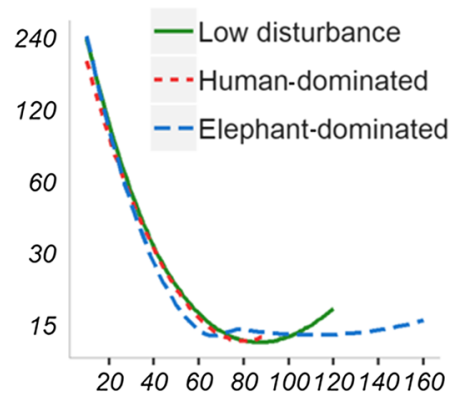

Fig. 2 Stem size distributions under different disturbance regimes. The reverse-J shaped stem size distributions (a) had shorter tail of large-size stems $(>35 \mathrm{~cm}$ ) in Human-dominated and a longer tail in Elephant-dominated plots (b) 
Fig. 3 The effect of disturbance regime on woodland structure in $20 \mathrm{~m}$ radius plots. Lines denote predicted estimates, with solid lines indicating significant, and dashed lines non-significant, effects (within 95\% CI). The shaded areas are the $95 \%$ CIs. Colours indicate type of the impact-elephant (blue) and human (orange). Both human and elephant disturbance were associated with reducing stem density but had dissimilar effects on other attributes of the woodland structure
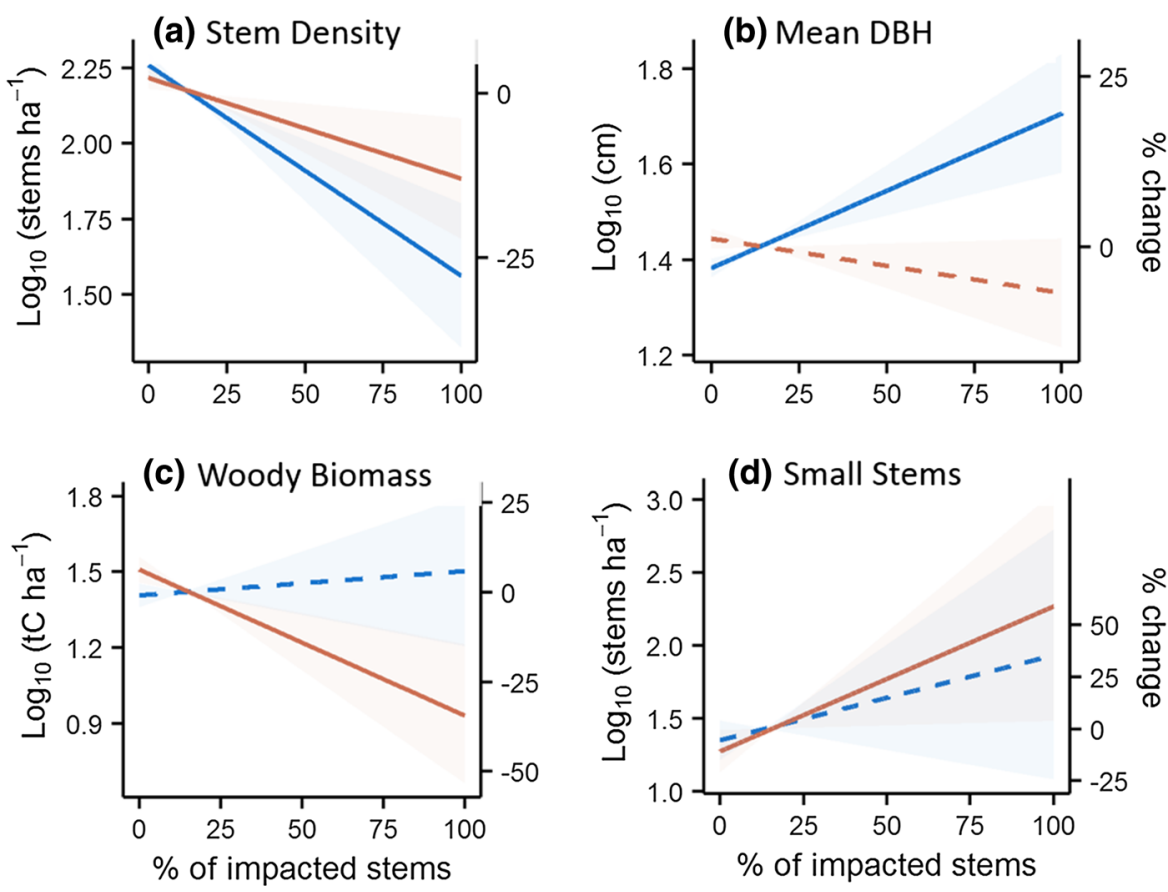

Elephant impact

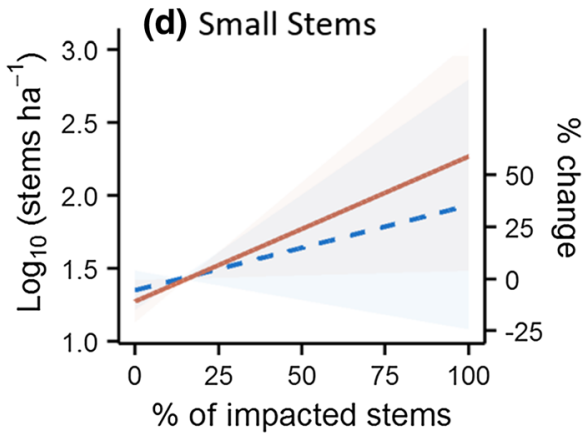

Human impact (a) Low disturbance woodland

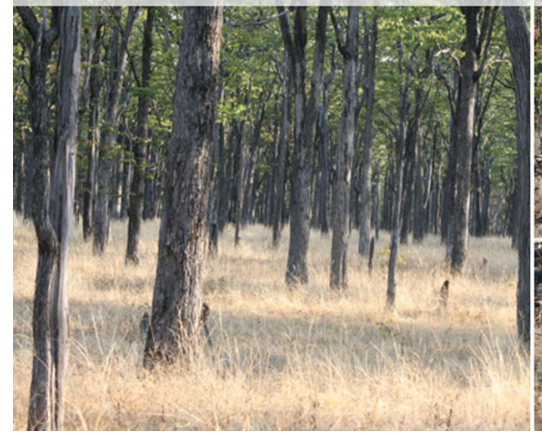

(b) Human-dominated woodland

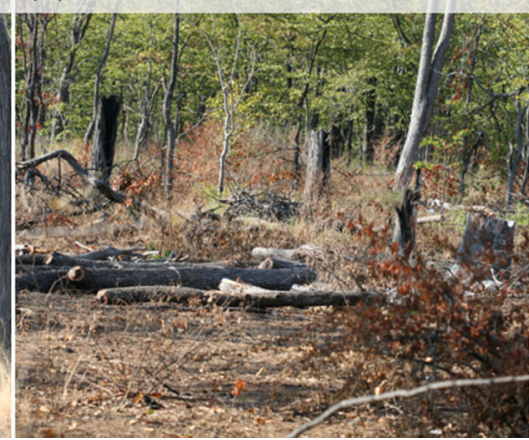

(c) Elephant-dominated woodland

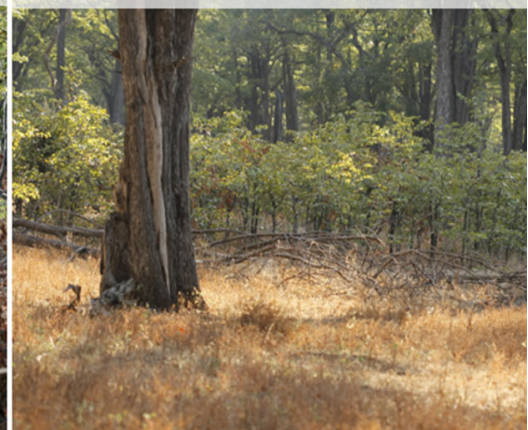

Fig. 4 Examples of mopane woodland under different disturbance regimes. The mopane woodlands with relatively low disturbance (a) have relatively high stem density and a mixture of stems of different size classes. In the more human-affected woodlands (b), large trees are selectively harvested, leading to reduced density, loss of woody biomass, and an increase in

namaquus; Batis molitor, Chrysococcyx klaas, Clamator levaillantii, Dendropicos fuscescens, and Eurystomus glaucurus). Thus, $I_{\text {Ele }}$ was primarily associated with declines in non-woodland birds, whereas $I_{\text {Human }}$ was associated with reductions in woodland-specific birds (Fig. 6).

Inclusion of environment variables did not make any difference to our results; in other words, small-stem density. Elephant-dominated woodlands (c) contain smaller stems which are frequently browsed by elephants, and occasional stems of larger size classes which have escaped elephant impact. These large stems maintain the plot-level woody biomass

environmental variables are not contributing to the differences we detected.

\section{Discussion}

Our study is the first to demonstrate that the replacement of elephants with humans as a major agent of 
Fig. 5 The effect of disturbance agent on species and functional bird diversity. Lines denote predicted estimates with solid lines indicating significant and dashed lines non-significant effects (within 95\% CI). Shaded area shows the $95 \%$ CI. Both human (red line) and elephant (blue) disturbances were associated reductions in species richness, but only human disturbances were associated with significant declines in functional bird diversity
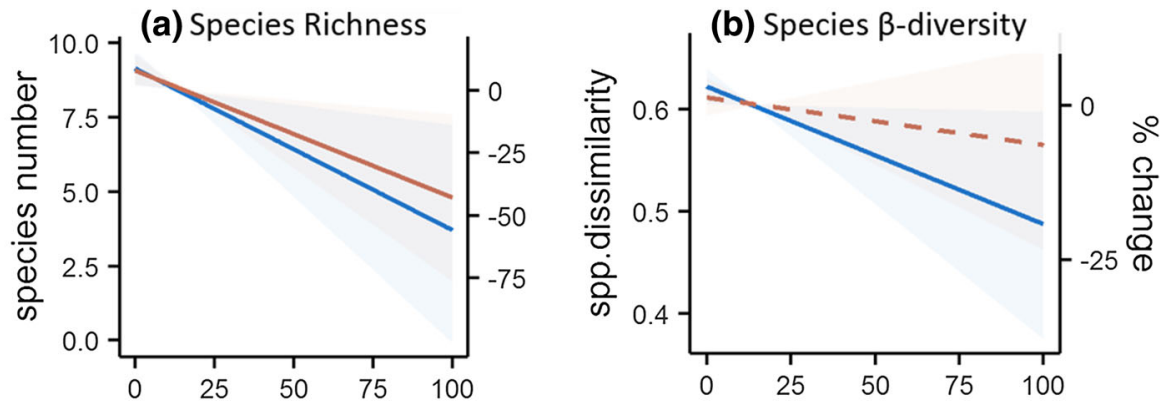

(c) Functional Diversity

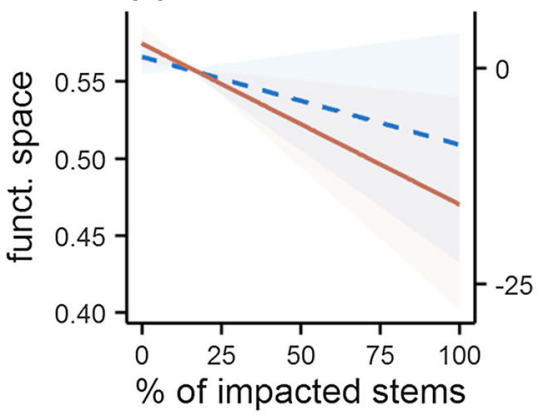

Elephant impact

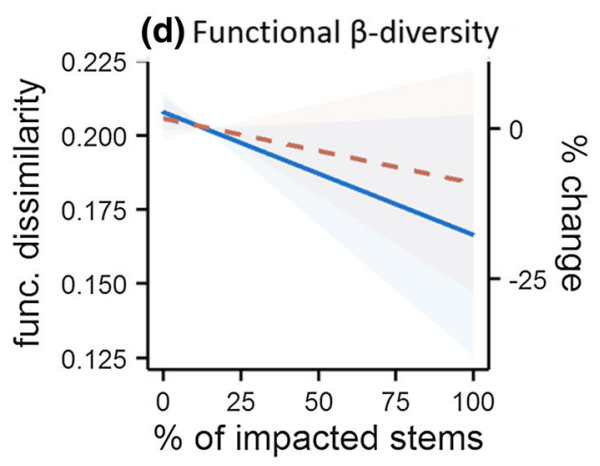

Human impact disturbance can alter the structure of savannas and have negative effects on bird biodiversity and functionality.

\section{Effects on woodland structure}

As expected, both humans and elephants were associated with reduced tree densities. The treefall rates reported in other studies (Asner and Levick 2012; Mograbi et al. 2017) are consistent with the patterns observed here, and are $7.7 \pm 1.6 \% \mathrm{ha}^{-1}$ by elephants and $3.5 \pm 1.4 \% \mathrm{ha}^{-1}$ by humans. This study provides mopane woodland specific support to the findings of Mograbi et al., (2017) in Kruger National Park that the magnitude of tree removal by elephants is generally higher than that of humans.

Despite a greater negative effect on tree density, elephant disturbance did not significantly reduce woody biomass, since elephant disturbance was associated with an increase in mean tree size. The relatively more frequent presence of larger trees $(>35 \mathrm{~cm} \mathrm{DBH}$ or $11 \mathrm{~m}$ height) in the elephantdisturbed areas counterbalanced the lost woody biomass as elephants damaged smaller trees. Elephants are known to predominantly utilize the smaller stems for browse and selectively revisit and reuse the previously utilized woodland patches which produce more nutritious and easily accessible browse. Certain trees, however, episodically escape from the elephant browse-trap (Asner and Levick 2012; Staver and Bond 2014) becoming larger and less vulnerable to future elephant impacts. This phenomenon of the escape from the elephant impacts may explain the higher number of large trees in elephant-impacted areas compared to those of humans, evident from higher mean tree size and long tail of large-size stem classes. However, as elephant density increases, the chance of trees escaping the browse-trap will diminish, with a concomitant loss of woody biomass (Ben-Shahar 1996). This density-dependent impact of elephants is influenced by rainfall, which mitigates the damage by promoting higher woody cover (Hempson et al. 2015), and by fences, which aggravate it by confining elephants and thereby concentrating their activities (Guldemond and Van Aarde 2008). Our study areas were not fenced, and since we sampled north-south regions of the mopane distribution in Zambia, we covered a representative range of rainfall. The observations made during this study are therefore considered to be generalizable, at least across Zambia and 


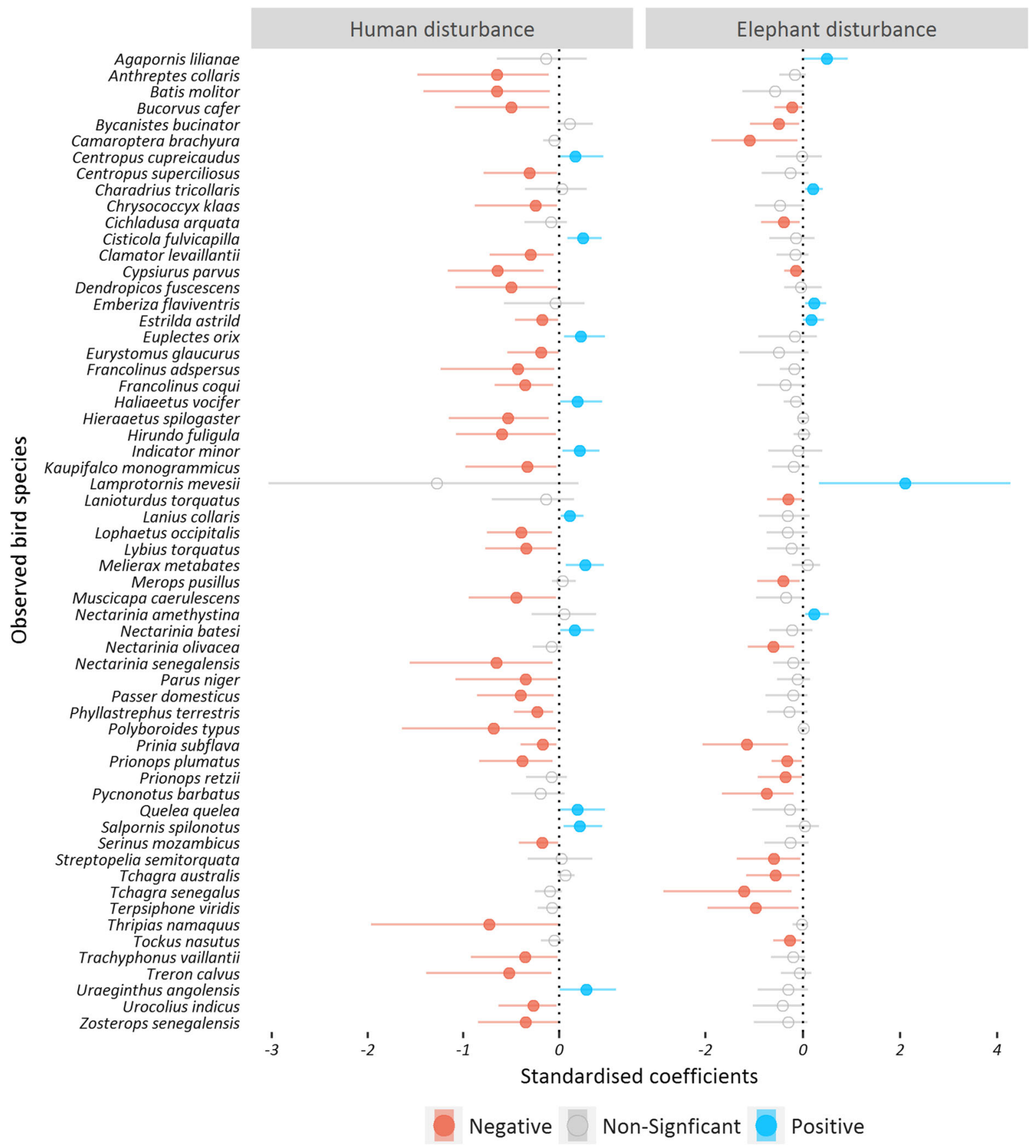

Fig. 6 The effect of human and elephant disturbance on species presence. The dots represent scaled model coefficients (proportion of deviance from the intercept), horizontal lines indicate $95 \% \mathrm{CI}$, and colours denote direction of the significant (95\% CI)

regions with similar climatic and edaphic conditions. In addition, our finding that elephant disturbance has no significant impact on woody biomass supports the relationship. For both disturbance there are more losses than gains in species incidence probability. Only species with at least one significant effect $(n=60)$ are shown

consensus in the literature that, at moderate densities at least, elephants have little impact on woody biomass (Ben-Shahar 1996; Guldemond and Van Aarde 2008; 
Kalwu et al. 2010). We acknowledge that what constitutes 'moderate' density is debatable, and that the definition varies between studies (Ben-Shahar 1996; Holdo et al. 2009; Kalwu et al. 2010); further research would be needed to draw objective thresholds.

While elephants mainly affect smaller trees, human use of the woodland is primarily driven by the need for timber and fuelwood, especially for charcoal production, leading to upsurge in selective logging of large stems (Hosier 1993; Ndegwa et al. 2016; Woollen et al. 2016). Therefore, in human-dominated landscapes, large trees face high selective pressure and rarely escape the human impact (Woollen et al. 2016; Mograbi et al. 2017). Hence, at the landscape level, human-affected areas are likely to undergo a decline in number of large stems and woody biomass, leaving behind small undesired or coppicing stems (Backéus et al. 2006; Fontodji et al. 2011; Ndegwa et al. 2016; Kiruki et al. 2017). As humans replace elephants as dominant agents of disturbance, the mopane woodlands are, therefore, more likely to become lowbiomass degraded systems, degraded from the perspective of carbon storage (McNicol et al. 2018).

\section{Effects on bird diversity}

Human and elephant disturbance both caused reductions in bird species richness-likely by removing trees that birds exploit for food and nesting (Skowno and Bond 2003) — but had dissimilar effects on other bird diversity attributes; functional diversity only reduced in response to human disturbance, whereas the species and functional $\beta$-diversities decreased with elephant disturbance.

The open-canopied mopane woodlands provide a characteristic habitat for cavity nesting, ground foraging, and canopy-specialist birds-the woodland species (Herremans 1995). A less disturbed woodland containing trees of diverse size classes has high habitat heterogeneity and supports bird communities composed of the dominant woodland species as well as the locally infrequent non-woodland species (Herremans 1995). While, the dominant woodland species form the core of the bird community, the infrequent nonwoodland species largely determine the compositional variability-the spatial $\beta$-diversity (Socolar et al. 2016). Although both human and elephant disturbances were associated with reductions in bird species richness, the type of species that were affected differed between human and elephant disturbances. Elephant disturbance was positively associated with the woodland bird species-functionally unique to the woodland bird communities, whereas human disturbance was positively associated with the infrequent nonwoodland species.

As the elephant-dominated areas maintained the dominant-and functionally unique-species of the community and lost only the infrequent bird species, the bird communities underwent spatial taxonomic and functional homogenization in response to elephant disturbance, i.e. a reduction in the turnover component of species and functional $\beta$-diversity (Socolar et al. 2016). Despite a reduction in functional turnover, there was no significant difference in functional alpha diversity, demonstrating high functional redundancy of bird communities in elephant-disturbed areas. In contrast, in the human-dominated areas, where the woodland structure is transformed into shrubby system, the dominant woodland bird species are reduced, and the infrequent non-woodland species are retained. This may explain the reduction in bird species richness and functional diversity without any significant effects on $\beta$-diversity. In circumstances where the woodlands are completely transformed into novel systems (e.g. croplands), the majority of the dominant woodland bird species may be replaced by the infrequent nonwoodland bird species causing significant increase in $\beta$-diversity and compositional drift of bird communities (Socolar et al. 2016).

Our finding that the human-led habitat modification reduces species and functional diversity is consistent with other studies (Flynn et al. 2009; Luck et al. 2013). However, the finding of dissimilar effects of human and elephant mediated habitat modification on species and functional diversity is novel. The results here indicate that despite losing some species, elephant disturbed woodlands maintain functional bird diversity. However, given that spatial functional $\beta$-diversity is reduced, the functional resilience of bird communities in elephant disturbed areas may be compromised. Importantly, elephant-dominated landscapes contain species of high conservation value like Agapornis lilianae (endemic to the mopane woodlands of the Zambezi basin and near threatened) and woodland specialist bird species such as Emberiza flaviventris, Parus niger and Thripias namaquus. 
These findings imply that to manage the negative effects of human disturbance on woodland birds, large trees $(\geq 0.35 \mathrm{~m} \mathrm{DBH}$ or $\geq 11 \mathrm{~m}$ height - the mean values in elephant-dominated areas) should be retained in the landscape. In our study area, this might be achieved by altering the charcoal and timber license conditions issued by the Forest Department in Zambia. Finally, this study is a snapshot of the complex dynamics of human and elephant interactions in the African woodlands. Although it only examined spatial variability, it provides an indication of how woodland structure and bird diversity may respond to changing disturbance regimes over time. More studies with spatial and temporal replications are required to better understand the dynamics of human and elephant mediated changes in woodland structure and biodiversity.

In summary, this study concludes the following:

(i) Although both modes of disturbance are associated with reduction in tree density, elephant disturbance does not necessarily reduce woody biomass, due to an increase in mean tree diameter. This increase is driven by the size-structured episodic escape of certain trees from the elephant browse trap (Asner and Levick 2012; Staver and Bond 2014). The escaped trees grow larger, and consequently become less vulnerable to elephant disturbance. In the densities at which they occur in the Zambian mopane region (0.44 km ${ }^{-2}$; DNPW 2016), elephants currently do not affect large tree populations substantially.

(ii) In the human-utilized areas, on the other hand, humans selectively harvest larger trees for fuelwood (especially charcoal production) and timber, thereby reducing mean tree size and woody biomass at the same time as tree density and promoting an increase in the density of small stems.

(iii) The dissimilar effects of human and elephant disturbance on woodland structure are apparent in patterns of bird diversity. Although both human and elephant disturbance were associated with reductions in bird species richness, only human disturbance was associated with reductions in functional bird diversity. The woodland-specific dominant bird functional groups (ground foraging plant and insectivores) which were not affected by elephant disturbance showed a negative response to human disturbance. In other words, elephant disturbance is associated with declines in non-woodland non-ubiquitous species which contribute very little to the functional diversity of the woodland bird communities, whereas human disturbance is associated with declines in ubiquitous species of the woodland resulting in functional decay.

(iv) Although elephant disturbance does not reduce functional bird diversity, it does decrease species as well as functional $\beta$ diversity, possibly via a reduction in landscape-scale habitat heterogeneity.

Acknowledgements The authors thank the two anonymous reviewers for their critical and constructive comments, which helped to improve the manuscript. Fieldwork of this study was funded by World Parrot Trust. Fieldwork permissions in national parks was facilitated by the BirdWatch Zambia and assistance was provided by the Zambia Wildlife Authority. We thank Mike Bingham, Lusaka, for help in plant identifications. We acknowledge support from the Abrupt Changes in Ecosystem Services project (NE/K010395/1) which was funded with support from the Ecosystem Services for Poverty Alleviation (ESPA) programme. The ESPA programme is funded by the Department for International Development (DFID), the Economic and Social Research Council (ESRC) and the Natural Environment Research Council (NERC). We also thank Dr Andrew Dobson and Dr Rose Pritchard for proof reading this manuscript and providing comments.

Open Access This article is distributed under the terms of the Creative Commons Attribution 4.0 International License (http:// creativecommons.org/licenses/by/4.0/), which permits unrestricted use, distribution, and reproduction in any medium, provided you give appropriate credit to the original author(s) and the source, provide a link to the Creative Commons license, and indicate if changes were made.

Author contributions HT, CR, TG, RM and CLP conceived the ideas and designed methodology; HT, TG and CP collected the data; HT analysed the data; HT led the writing of the manuscript. All authors contributed critically to the drafts and gave final approval for publication. The authors declare no conflict of interest.

Data accessibility Data and $\mathrm{R}$ codes used in this study are available from the Git Repository. https://bitbucket.org/ed_ trop_land_use/2018_birdhab_zambia/src. 


\section{References}

Andela N, Morton DC, Giglio L, Chen Y, van der Werf GR, Kasibhatla PS, Defries RS, Collatz GJ, Hantson S, Kloster S, Bachelet D, Forrest M, Lasslop G, Li F, Mangeon S, Melton J, Yue C, Randerson JT (2017) A human-driven decline in global burned area. Science 356:1356-1362. https://doi.org/10.1126/science.aal4108

Archibald S (2016) Managing the human component of fire regimes: lessons from Africa. Philos Trans R Soc B Biol Sci 371:20150346. https://doi.org/10.1098/rstb.2015.0346

Asner GP, Levick SR (2012) Landscape-scale effects of herbivores on treefall in African savannas. Ecol Lett 15:1211-1217. https://doi.org/10.1111/j.1461-0248.2012. 01842.x

Backéus I, Pettersson B, Strömquist L, Ruffo C (2006) Tree communities and structural dynamics in miombo (Brachystegia-Julbernardia) woodland, Tanzania. For Ecol Manage 230:171-178. https://doi.org/10.1016/j.foreco. 2006.04.033

Baselga A (2010) Partitioning the turnover and nestedness components of beta diversity. Global Ecol Biogeogr 19(1):134-143. https://doi.org/10.1111/j.1466-8238.2009. 00490.x

Benítez-López A, Alkemade R, Schipper AM, Ingram DJ, Verweij PA, Eikelboom JAJ, Huijbregts MAJ (2017) The impact of hunting on tropical mammal and bird populations. Science 356:180-183. https://doi.org/10.1126/ science.aaj1891

Ben-Shahar R (1996) Do elephants over-utilize mopane woodlands in northern Botswana? J Trop Ecol 12:505. https:// doi.org/10.1017/S0266467400009731

Bibby CJ (1999) Making the most of birds as environmental indicators. Ostrich 70:81-88. https://doi.org/10.1080/ 00306525.1999 .9639752

Bingham MG, Willemen A, Wursten BT, Ballings P, Hyde MA (2017) Flora of Zambia. www.zambiaflora.com

Botes A, McGeoch MA, van Rensburg BJ (2006) Elephant- and human-induced changes to dung beetle (Coleoptera: Scarabaeidae) assemblages in the Maputaland Centre of Endemism. Biol Conserv 130:573-583. https://doi.org/10. 1016/j.biocon.2006.01.020

Charles-Dominique T, Davies TJ, Hempson GP, Bezeng BS, Daru BH, Kabongo RM, Maurin O, Muasya AM, van der Bank M, Bond WJ (2016) Spiny plants, mammal browsers, andthe origin of African savannas. Proc Natl Acad Sci U S A. https://doi.org/10.1073/pnas.1607493113

Chomba C, Simukonda C, Nyirenda V, Chisangano F (2012) Population status of the African elephant in Zambia. J Ecol Nat Environ. https://doi.org/10.5897/jene11.142

Cumming DHM, Fenton MB, Rautenbach IL, Taylor RD, Cumming GS, Cumming MS, Dunlop JM, Ford AG, Hovorka MD, Johnston DS, Kalcounis M, Mahlangu Z, Portfors CVR (1997) Elephants, woodlands and biodiversity in Southern Africa. S Afr J Sci 93:231-236. https://doi. org/10.1371/journal.pone.0097910

de Boer WF, van Langevelde F, Prins HHT, de Ruiter PC, Blanc J, Vis MJP, Gaston KJ, Hamilton ID (2013) Understanding spatial differences in African elephant densities andoccurrence, A continent-wide analysis. Biol Conserv
159:468-476. https://doi.org/10.1016/j.biocon.2012.10. 015

DNPW (2016) The 2015 Aerial Survey in Zambia. Population Estimates of African Elephants (Loxodonta africana) in Zambia. Chilanga, Zambia. Cover

Dray AS, Blanchet G, Borcard D, Guenard G, Jombart T, Larocque G, Legendre P, Madi N, Wagner HH (2016) adespatial: Multivariate Multiscale Spatial Analysis. R package, Version: 0.0-7

Ellis EC (2011) Anthropogenic transformation of the terrestrial biosphere. Philos Trans R Soc A Math Phys Eng Sci 369:1010-1035. https://doi.org/10.1098/rsta.2010.0331

Flynn DFB, Gogol-Prokurat M, Nogeire T, Molinari N, Richers BT, Lin BB, Simpson N, Mayfield MM, DeClerck F (2009) Loss of functional diversity under land use intensification across multiple taxa. Ecol Lett 12(1):22-33. https://doi. org/10.1111/j.1461-0248.2008.01255.x

Fontodji JK, Atsri H, Adjonou K, Radji AR, Kokutse AD, Nuto Y, Kokou K (2011) Impact of Charcoal Production on Biodiversity in Togo (West Africa). Import Biol Interact Study Biodivers. https://doi.org/10.5772/22969

Gelman A, Rubin DB (1992) Inference from Iterative Simulation Using Multiple Sequences. Stat Sci 7:457-472. https:// doi.org/10.1214/ss/1177011136

Gregory RD, Gibbons DW, Donald PF (2004) Bird census and survey techniques. In: Bird ecology and conservation: a handbook of techniques. pp 17-55

Guldemond R, Purdon A, Van Aarde R (2017) A systematic review of elephant impact across Africa. PLoS ONE 12:1-12. https://doi.org/10.1371/journal.pone.0178935

Guldemond R, Van Aarde RUDI (2008) A Meta-Analysis of the Impact of African Elephants on Savanna Vegetation. J Wildl Manage 72:892-899. https://doi.org/10.2193/ 2007-072

Gumbo DJ, Moombe KB, Kandulu MM, Kabwe G, Ojanen M, Ndhlovu E, Sunderland TCH (2013) Dynamics of the charcoal and indigenous timber trade in Zambia: A scoping study in Eastern, Northern and Northwestern provinces. Center for International Forestry Research (CIFOR), Bogor

Hempson GP, Archibald S, Bond WJ (2015) A continent-wide assessment of the form and intensity of large mammal herbivory in Africa. Science (80-) 350:1056-61. https:// doi.org/10.1126/science.aac7978

Hempson GP, Archibald S, Bond WJ (2017) The consequences of replacing wildlife with livestock in Africa. Sci Rep 7:. https://doi.org/10.1038/s41598-017-17348-4

Herremans M (1995) Effects of woodland modification by African elephant Loxodonta africana on bird diversity in northern Botswana. Ecography (Cop) 18:440-454. https:// doi.org/10.1111/j.1600-0587.1995.tb00147.x

Hoare RE, du Toit JT (1999) Coexistence between people and elephants in African savannas. Conserv Biol 13:633-639. https://doi.org/10.1046/j.1523-1739.1999.98035.x

Holdo RM, Holt RD, Fryxell JM (2009) Grazers, browsers, and fire influence the extent andspatial pattern of tree cover in the Serengeti. Ecol Appl 19:95-109. https://doi.org/10. 1890/07-1954.1

Hosier RH (1993) Charcoal production and environmental degradation. Energy Policy 21:491-509. https://doi.org/10. 1016/0301-4215(93)90037-G 
Hyde MA, Wursten BT, Ballings P, Palgrave CM (2017) Flora of Zimbabwe. www.zimbabweflora.co.zw

Kalema VN, Witkowski ETF (2012) Land-use impacts on woody plant density and diversity in an African savanna charcoal production region. Int $\mathbf{J}$ Biodivers Sci Ecosyst Serv Manag 8:231-247. https://doi.org/10.1080/21513732. 2012.681070

Kalwu JM, De Boer WF, Mucina L, Prins HHT, Skarpe C, Winterbach C (2010) Tree cover and biomass increase in a southern African savanna despite growing elephant population. Ecol Appl 20:222-233. https://doi.org/10.1890/090541.1

Kampamba G, Chansa W, Kabeta HM, Saiwana L, Siamudaala V, Simwanza H (2003) National policy and action plan on elephant management in Zambia

Kellner K (2015) jagsUI: a wrapper around rjags to streamline JAGS analyses. R Packag version 1:

Kéry M, Royle JA (2016) Applied Hierarchical Modeling in Ecology. Appl Hierarchical Model Ecol 79-122. https:// doi.org/10.1016/b978-0-12-801378-6.00003-5

Kiruki HM, van der Zanden EH, Gikuma-Njuru P, Verburg PH (2017) The effect of charcoal production and other land uses on diversity, structure and regeneration of woodlands in a semi-arid area in Kenya. For Ecol Manage 391:282-295. https://doi.org/10.1016/j.foreco.2017.02. 030

Kohi EM, de Boer WF, Peel MJS, Slotow R, van der Waal C, Heitkönig IMA, Skidmore A, Prins HHT (2011) African Elephants Loxodonta africana Amplify Browse Heterogeneity in African Savanna. Biotropica 43:711-721. https://doi.org/10.1111/j.1744-7429.2010.00724.x

Leprieur F, Albouy C, de Bortoli J, Cowman PF, Bellwood DR, Mouillot D (2012) Quantifying phylogenetic beta diversity: Distinguishing between "true" turnover of lineages and phylogenetic diversity gradients. PLoS ONE. https:// doi.org/10.1371/journal.pone.0042760

Luck GW (2007) A review of the relationships between human population density and biodiversity. Biol Rev 82:607-645. https://doi.org/10.1111/j.1469-185X.2007.00028.x

Luck GW, Carter A, Smallbone L (2013) Changes in Bird Functional Diversity across Multiple LandUses: Interpretations of Functional Redundancy Depend on Functional Group Identity. PLoS ONE. https://doi.org/10.1371/ journal.pone.0063671

Martini F, Cunliffe R, Farcomeni A, De Sanctis M, D'Ammando G, Attorre F (2016) Classification and mapping of the woody vegetation of Gonarezhou National Park, Zimbabwe. Koedoe 58:1-10. https://doi.org/10.4102/koedoe. v58i1.1388

McNicol IM, Ryan CM, Mitchard ETA (2018) Carbon losses from deforestation and widespread degradation offset by extensive growth in African woodlands. Nat Commun $1-19$

Melo AS (2016) Community Ecology Analyses

Melo AS, Cianciaruso MV, Almeida-Neto M (2014) treeNODF: Nestedness to phylogenetic, functional and other treebased diversity metrics. Methods Ecol Evol 5(6):563-572. https://doi.org/10.1111/2041-210X.12185

Mograbi PJ, Asner GP, Witkowski ETF, Erasmus BFN, Wessels KJ, Mathieu R, Vaughn NR (2017) Humans and elephants as treefall drivers in African savannas. Ecography (Cop) 40:1274-1284. https://doi.org/10.1111/ecog.02549

Mzumara TI, Perrin MR, Downs CT (2014) Distribution of Lilian's Lovebirds in Malawi. Ostrich 85:267-272. https:// doi.org/10.2989/00306525.2014.963187

Ndegwa GM, Nehren U, Grüninger F, Iiyama M, Anhuf D (2016) Charcoal production through selective logging leads to degradation of dry woodlands: a case study from Mutomo District, Kenya. J Arid Land 8:618-631. https:// doi.org/10.1007/s40333-016-0124-6

Nkhuwa DCW, Kang'omba S, Chomba KC, Crane E, Upton K, Ó Dochartaigh B (2016) Africa Groundwater Atlas: Hydrogeology of Zambia. In: Br. Geol. Surv. http:// earthwise.bgs.ac.uk/index.php/Hydrogeology_of_Zambia

O'Connor TG, Goodman PS, Clegg B (2007) A functional hypothesis of the threat of local extirpation of woody plant species by elephant in Africa. Biol Conserv 136:329-345. https://doi.org/10.1016/j.biocon.2006.12.014

Ohadike P, Tesfaghiorghis H (1975) The population of Zambia. World Popul Year 68:61-68. https://doi.org/10.1080/ 00369225008735447

Oksanen J, Blanchet FG, Friendly M, Kindt R, Legendre P, McGlinn D, Minchin PR, O'Hara RB, Simpson GL, Solymos P, Stevens MHH, Szoecs E, Wagner H (2016) vegan: community ecology package. R Packag version 24-1 Available at: https://cran.r-project.org/web/packa. https://doi.org/10.4135/9781412971874.n145

Owens IPF, Bennett PM (2000) Ecological basis of extinction risk in birds: habitat loss versus human persecution and introduced predators. Proc Natl Acad Sci 97:12144-12148. https://doi.org/10.1073/pnas.200223397

Pringle RM (2008) Elephants as agents of habitat creation for small vertebrates at the patch scale. Ecology 89:26-33. https://doi.org/10.1890/07-0776.1

R Core Team (2017) R: a Language and Environment for Statistical Computing. R Found. Stat. Comput. 55:275-286

Robson AS, Trimble MJ, Purdon A, Young-Overton KD, Pimm SL, Van Aarde RJ (2017) Savanna elephant numbers are only a quarter of their expected values. PLoS ONE. https:// doi.org/10.1371/journal.pone.0175942

Ryan CM, Williams M, Grace J (2011) Above- and belowground carbon stocks in a miombowoodland landscape of mozambique. Biotropica 43(4):423-432. https://doi.org/ 10.1111/j.1744-7429.2010.00713.x

Seymour CL, Dean WRJ (2010) The influence of changes in habitat structure on the species composition of bird assemblages in the southern Kalahari. Austral Ecol 35:581-592. https://doi.org/10.1111/j.1442-9993.2009. 02069.x

Shannon G, Thaker M, Vanak AT, Page BR, Grant R, Slotow R (2011) Relative Impacts of Elephant and Fire on Large Trees in a Savanna Ecosystem. Ecosystems 14:1372-1381. https://doi.org/10.1007/s10021-011-9485-z

Skowno AL, Bond WJ (2003) Bird community composition in an actively managed savanna reserve, importance of vegetation structure and vegetation composition. Biodivers Conserv 12:2279-2294. https://doi.org/10.1023/A: 1024545531463

Socolar JB, Gilroy JJ, Kunin WE, Edwards DP (2016) How should beta-diversity inform biodiversity conservation? Trends Ecol Evol 31:61-80 
Staver AC, Bond WJ (2014) Is there a "browse trap"? Dynamics of herbivore impacts on trees and grasses in an African savanna. J Ecol 102:595-602. https://doi.org/10.1111/ 1365-2745.12230

Stevens N, Erasmus BFN, Archibald S, Bond WJ (2016) Woody encroachment over 70 years in South African savannahs: overgrazing, global change or extinction aftershock? Philos Trans R Soc B 371:20150437. https://doi.org/10.1098/ rstb.2015.0437

Styles CV, Skinner JD (2000) The influence of large mammalian herbivores on growth form and utilization of mopane trees, Colophospermum mopane, in Botswana's Northern Tuli Game Reserve. Afr J Ecol 38:95-101. https://doi.org/10. 1046/j.1365-2028.2000.00216.x

Swenson NG (2014) Functional and Phylogenetic Ecology in R Wickham H (2009) ggplot2: elegant Graphics for Data Analysis. Springer 35:211. https://doi.org/10.1007/978-0-38798141-3
Wilman H, Belmaker J, Jennifer S, de la Rosa C, Rivadeneira MM, Jetz W (2014) EltonTraits 1. 0: species-level foraging attributes of the world' $\mathrm{s}$ birds and mammals. Ecology 95:2027. https://doi.org/10.1890/13-1917.1

Winfree R, Griswold T, Kremen C (2007) Effect of human disturbance on bee communities in a forested ecosystem. Conserv Biol 21:213-223. https://doi.org/10.1111/j.15231739.2006.00574.x

Woollen E, Ryan C, Grundy I, Baumert S, Vollmer F, Fernando J, Luz A, Ribeiro N, Fisher J, Lisboa SN (2016) Charcoal production in the Mopane woodlands of Mozambique: what are the tradeoffs with other ecosystem services? Philos Trans R Soc B. https://doi.org/10.1098/rstb.2015. 0315

Publisher's Note Springer Nature remains neutral with regard to jurisdictional claims in published maps and institutional affiliations. 